\title{
Students' Cognitive Learning Outcomes In Simple Machine Subjects Through REACT Learning Model
}

\author{
Haris Rosdianto ${ }^{1}$, Umi Hafizah Syahandri ${ }^{2}$, Natcha Mahapoonyanont ${ }^{3}$ \\ STKIP Singkawang, Indonesia ${ }^{1,2}$, Thaksin University, Thailand ${ }^{3}$ \\ harisrosdianto@yahoo.com ${ }^{1}$, umisyahandri@yahoo.com ${ }^{2}$, natcha@ scholar.tsu.ac.th ${ }^{3}$
}

Received: April $16^{\text {th }}, 2020$. Revised: May 19 ${ }^{\text {th }}, 2020$. Accepted: May $26^{\text {th }}, 2020$

\author{
Keywords : \\ REACT Learning Model; \\ Cognitive Learning Outcomes; \\ Pre-experimental; Simple \\ Machine
}

\begin{abstract}
This study aims to determine how much improvement in students' cognitive learning outcomes after applying the REACT learning model on simple machine subjects. This type of research is quantitative research in the form of preexperimental design. The population in this study were all eighth grade students of SMP Negeri 1 Jawai, Sambas Regency, West Kalimantan. The sample in this study were 25 class VIIIC students, determined by the purposive sampling technique. This research begins with the provision of pretest followed by treatment in the form of application of the REACT learning model and ends with the administration of posttest. From the data analysis, it was found that the cognitive learning outcomes of students experienced an increase of 0.44 based on the N-gain equation with the medium category. The recapitulation results from the attitude scale showed that $87 \%$ of students stated that they were better able to understand simple machine subjects using the REACT learning model. It can be concluded that the REACT learning model can improve student learning outcomes on simple machine subjects.
\end{abstract}

\section{INTRODUCTION}

Natural sciences is science that studies natural phenomena that can be formulated empirically [1]. Natural sciences is not only about mastering a collection of knowledge in the form of facts, concepts, or formulas, but also is a process of discovery. In addition, the learning process of natural sciences should also provide experience for students to be able to construct the knowledge acquired. Students are directed to compare the results of their predictions with theory through experiments, so that students gain experience and deeper understanding [2].

Physics learning basically includes four main elements, namely: 1) attitudes, curiosity about natural phenomena, and causal relationships that cause new problems that can be solved through correct procedures; 2) process, problem solving procedures through scientific methods including preparation of hypotheses, design of experiments or experiments, evaluation, measurement, and drawing conclusions; 3) products, in the form of facts, principles, theories, and laws, along with 4) application of scientific methods and concepts of natural science in everyday life. In optimizing the application of the four 
aspects of physics learning, it is expected that later student achievement can be achieved optimally. However, the application of aspects of physics learning certainly needs to be supported by creative and innovative learning methods, adjusted to the level of student ability.

The cognitive domain focuses more on intellectual processes that includes mental activities (brain) [3]. The cognitive domain is divided into six levels: 1) remembering; 2) understanding; 3) applying; 4) analyzing; 5) evaluating; and 6) creating [4]. Student learning outcomes can be obtained by conducting tests and measurements. Tests and measurements require an instrument for evaluating learning outcomes. The instruments in this study consisted of test and non-test [5]. In taking measurements to determine learning outcomes, there are several factors that can influence it. The factors are internal factors and external factors.

Internal factors are factors that originate from within the individual and can influence individual learning outcomes. These internal factors include physiological and psychological factors [6]. Physiological factors can be divided into two, namely the physical conditions and physical function [6]. Physical conditions such as eyes, ears, mouth, and other senses are certainly very influential on the process of receiving learning and individual learning outcomes. Someone with a healthy physical condition will most likely be more receptive to learning compared to someone who has an unhealthy physical condition. While psychological factors are internal factors which are the main things that determine the intensity of learning and affect learning outcomes. The main psychological factors that influence the learning process and outcomes are interest, intelligence, talent, motivation, and cognitive abilities [7]. Psychological factors that influence the success of learning include everything related to their mental condition [4]. Therefore, it is necessary to develop the interests, talents, intelligence and mental conditions of students to improve their learning outcomes [8].

External factors come from outside the individual itself, include family environmental, school environmental, community environmental, and time [4]. External factors are divided into two, environmental and instrumental factors [9]. Environmental factors include the physical and social environment. Learning in the middle of the day in a room with less air circulation will be very influential and will be very different in learning in the morning where the conditions are still fresh and with enough room to breathe freely. The existence and use of instrumental factors are designed according to the expected learning outcomes. These factors are expected to help achieve the learning objectives.

In addition to the above factors, the learning model applied by the teacher in learning can be an important factor influencing student learning outcomes [10]. The learning model applied by the teacher is still monotonous and oriented to memorization of theory and is not based on student experience. The learning process that is less motivating students will affect student learning outcomes because students are not given the opportunity to develop responsibility, curiosity, confidence in interpreting natural phenomena scientifically [11].

Based on the results of interviews with one of the natural science teachers in SMP Negeri 1 Jawai, it was found that the science learning outcomes were still low. This can be seen from the daily tests of students in science learning approximately $80 \%$ are still below the Minimum Mastery Criteria. The low achievement of student learning outcomes due to the application of learning methods by teachers that are monotonous and less innovative, so students only become passive listeners who have no learning experience. This makes students quickly forget the material that has been given, and get bored in learning physics.

More effective learning can help students to improve their abilities and learning outcomes in accordance with the competencies to be achieved. The teacher should be more selective in determining the learning model that will be used according to the subject and level of student ability [12].

The learning model used in this study is the REACT (Relating, Experiencing, Applaying, Cooperating, Transfering) learning model. This learning model emphasizes the provision of information previously 
known to students, so students will more easily understand the concepts conveyed by the teacher because they tend to be found in everyday life [13]. The application of the REACT learning model is expected to provide a new nuance in the learning process.

The REACT learning strategy was introduced by the Center of Occupational Research and Development (CORD) which consisted of 5 stages: 1) relating, 2) experiencing, 3) applying, 4) cooperating, and 5) transferring [14]. REACT learning model is more focused on providing information relating to information previously known to students, so students will more easily understand the concepts conveyed by the teacher because they are often encountered in everyday life [15].

\section{METHOD}

This research was conducted in one class and with the pretest and posttest so the improvements can be seen. The design of this research is One Group Pretest-Posttest. Where all samples are given treatment for a certain time. Pretest is carried out before treatment and posttest is carried out after treatment. So it will be seen how the effect of treatment there is an increase in students' cognitive learning outcomes. This design can be seen in the following Table 1 .

Table 1. One Group Pretest-Posttest Design [16]

\begin{tabular}{ccc}
\hline Pretest & Treatment & Posttest \\
\hline $\mathrm{O}_{1}$ & $\mathrm{X}$ & $\mathrm{O}_{2}$ \\
\hline
\end{tabular}

Where:

$\mathrm{O}_{1}=$ pretest before the treatment

$\mathrm{O}_{2}=$ posttest after the treatment

$\mathrm{X}=$ the treatment of the experimental class with the REACT Learning Model

The population in this study were all students of class VIII at SMPN 1 Jawai, Sambas Regency. Purposive sampling technique is used to determine the research sample. The sampling considerations in this study were seen from the achievement of the average learning outcomes of Grade VIIIC students was lower than Minimum Mastery Criteria scores compared to other classes.

Data collection techniques used in this study are tests and non-tests. The test to measure students' abilities in the form of multiple choice is conducted to determine student learning outcomes on simple machine subjects. Tests are given before and after treatment. Whereas the non-test was in the form of questionnaire given after treatment, to describe students' responses to the application of the REACT learning model in physics learning.

To analyze the increase in student cognitive learning outcomes, $\mathrm{N}$-gain is used as a data analysis technique.

Where:

$$
\langle g\rangle=\frac{S_{\text {posttest }}-S_{\text {pretest }}}{S_{\text {max }}-S_{\text {pretest }}}
$$

$\begin{array}{ll}\langle g\rangle & =\text { Normalized gain or gain factor } \\ S_{\text {posttest }} & =\text { Posttest score } \\ S_{\text {pretest }} & =\text { Pretest score } \\ S_{\max } & =\text { Maximum score }\end{array}$


The $\mathrm{N}$-gain criteria shown in Table 2 are as follows.

Table 2. N-gain Criteria

\begin{tabular}{cc}
\hline Gain score & Criteria \\
\hline$\langle g\rangle \geq 0,7$ & High \\
$0,3 \leq\langle g\rangle<0,7$ & Medium \\
$\langle g\rangle<0,3$ & Low \\
\hline
\end{tabular}

To analyze student responses to the implementation of REACT learning model, response data that has been collected is converted into quantitative form [17]. The calculation for the percentage of students' responses is as follows.

Where:

$$
X \%=\frac{n}{N} \times 100 \%
$$

$X \%=$ Expected percentage score

$n=$ Number of students who agree

$N=$ Total number of students

The classification of student responses is shown in table 3 below.

Table 3. Students' Response Category

\begin{tabular}{cc}
\hline Interval Persentase & Kriteria \\
\hline $75 \% \leq X \% \leq 100 \%$ & Very Good \\
$50 \% \leq X \%<75 \%$ & Good \\
$25 \% \leq X \%<50 \%$ & Moderate \\
$0 \% \leq X \%<25 \%$ & Bad \\
\hline
\end{tabular}

\section{RESULTS AND DISCUSSIONS}

Improvement of Students' Cognitive Learning Outcomes

Students' learning outcomes data obtained from the average pretest and posttest score. The pretest and posttest scores obtained can be seen in Table 4 .

Table 4. Pretest and Posttest Results

\begin{tabular}{cccc}
\hline \multirow{2}{*}{ No } & \multirow{2}{*}{ Student' Code } & \multicolumn{2}{c}{ Score } \\
\cline { 3 - 4 } & & Pretest & Posttest \\
\hline 1 & A1 & 60 & 80 \\
2 & A2 & 60 & 80 \\
3 & A3 & 60 & 90 \\
4 & A4 & 50 & 80 \\
5 & A5 & 70 & 90 \\
6 & A6 & 50 & 70 \\
7 & A7 & 60 & 80 \\
8 & A8 & 60 & 70 \\
9 & A9 & 60 & 90 \\
10 & A10 & 60 & 70 \\
11 & A11 & 30 & 60 \\
\hline
\end{tabular}


JIPF, Vol. 5 No. 3, September 2020

\begin{tabular}{cccc}
\hline 12 & A12 & 60 & 70 \\
13 & A13 & 60 & 80 \\
14 & A14 & 50 & 60 \\
15 & A15 & 60 & 70 \\
16 & A16 & 50 & 70 \\
17 & A17 & 60 & 70 \\
18 & A18 & 50 & 70 \\
19 & A19 & 50 & 70 \\
20 & A20 & 60 & 90 \\
21 & A21 & 60 & 80 \\
22 & A22 & 50 & 80 \\
23 & A23 & 50 & 60 \\
24 & A24 & 60 & 80 \\
25 & A25 & 70 & 90 \\
\hline Total & & $\mathbf{1 , 4 1 0}$ & $\mathbf{1 9 0 0}$ \\
\hline Average & & $\mathbf{5 6 . 4}$ & $\mathbf{7 6}$ \\
\hline Highest score & & $\mathbf{7 0}$ & $\mathbf{9 0}$ \\
\hline Lowest score & & $\mathbf{3 0}$ & $\mathbf{6 0}$ \\
\hline
\end{tabular}

The graphs of the pretest and posttest results can be seen in Fig 1 below.

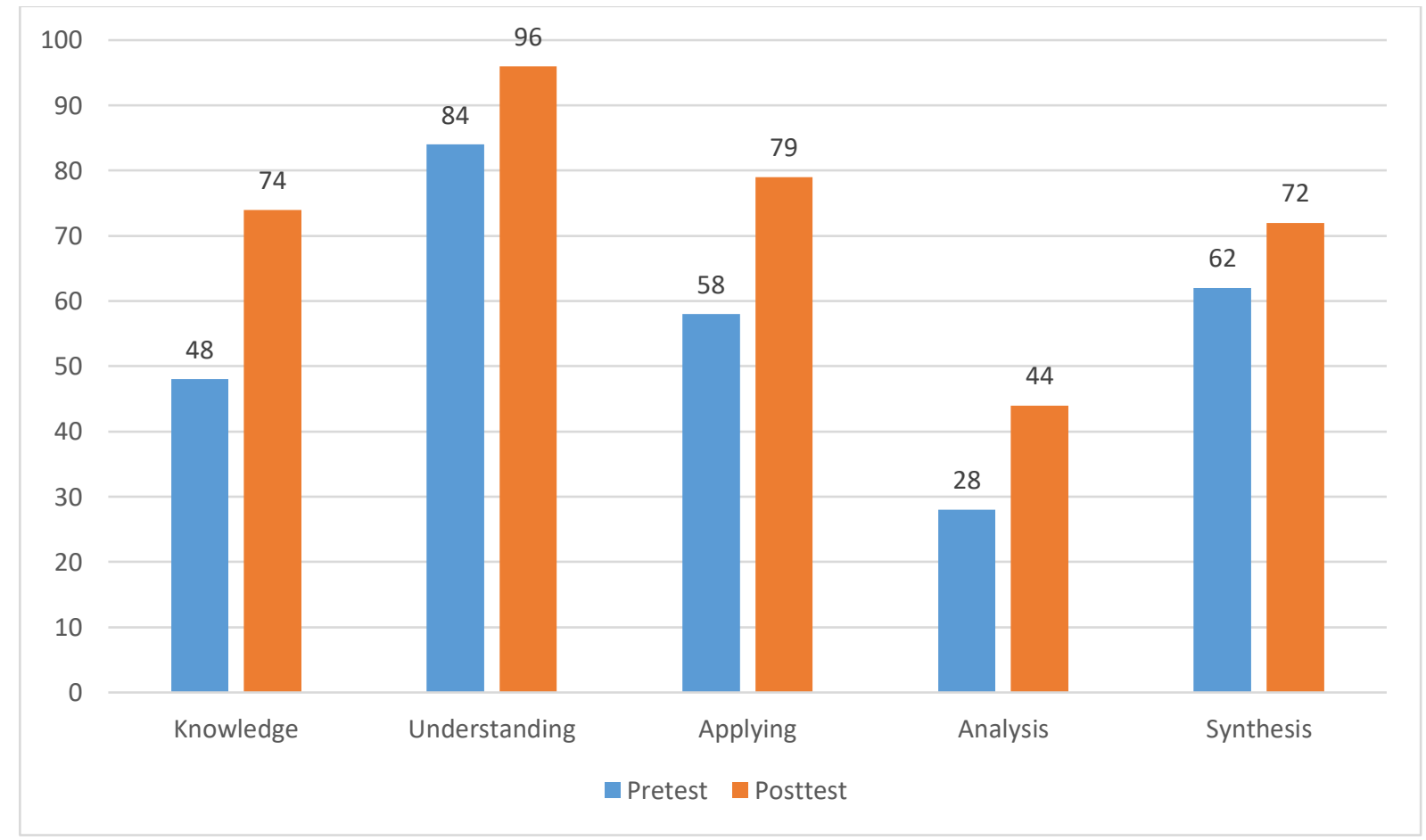

Fig 1. Graph of Pretest and Posttest Results

Based on aspects of students' cognitive learning outcomes and the improvement from each aspect of cognitive learning outcomes obtained from the number of correct answers from the maximum score can be seen in Table 5 . 
Students' Cognitive Learning Outcomes In Simple Machine Subjects Through REACT Learning Model Haris Rosdianto, Umi Hafizah Syahandri, Natcha Mahapoonyanont

Table 5. Improvement of Cognitive Learning Outcomes for each Aspect

\begin{tabular}{ccccc}
\hline Indicators of & \multicolumn{2}{c}{ Value } & \multicolumn{2}{c}{ N-gain } \\
\cline { 2 - 5 } Cognitive Learning & Pretest & Posttest & Score & Category \\
Outcomes & 48 & 74 & 0.5 & Medium \\
Knowledge & 84 & 96 & 0.75 & High \\
Understanding & 58 & 79 & 0.5 & Medium \\
Application & 28 & 44 & 0.22 & Medium \\
Analysis & 62 & 72 & 0.26 & Medium \\
Synthesis & $\mathbf{5 6 . 4}$ & $\mathbf{7 6}$ & $\mathbf{0 . 4 4}$ & Medium \\
\hline Cognitive Learning & & & & \\
Outcomes & & &
\end{tabular}

The graphs for the improvement of students' cognitive learning outcomes in every aspect can be seen in Fig 2 below.

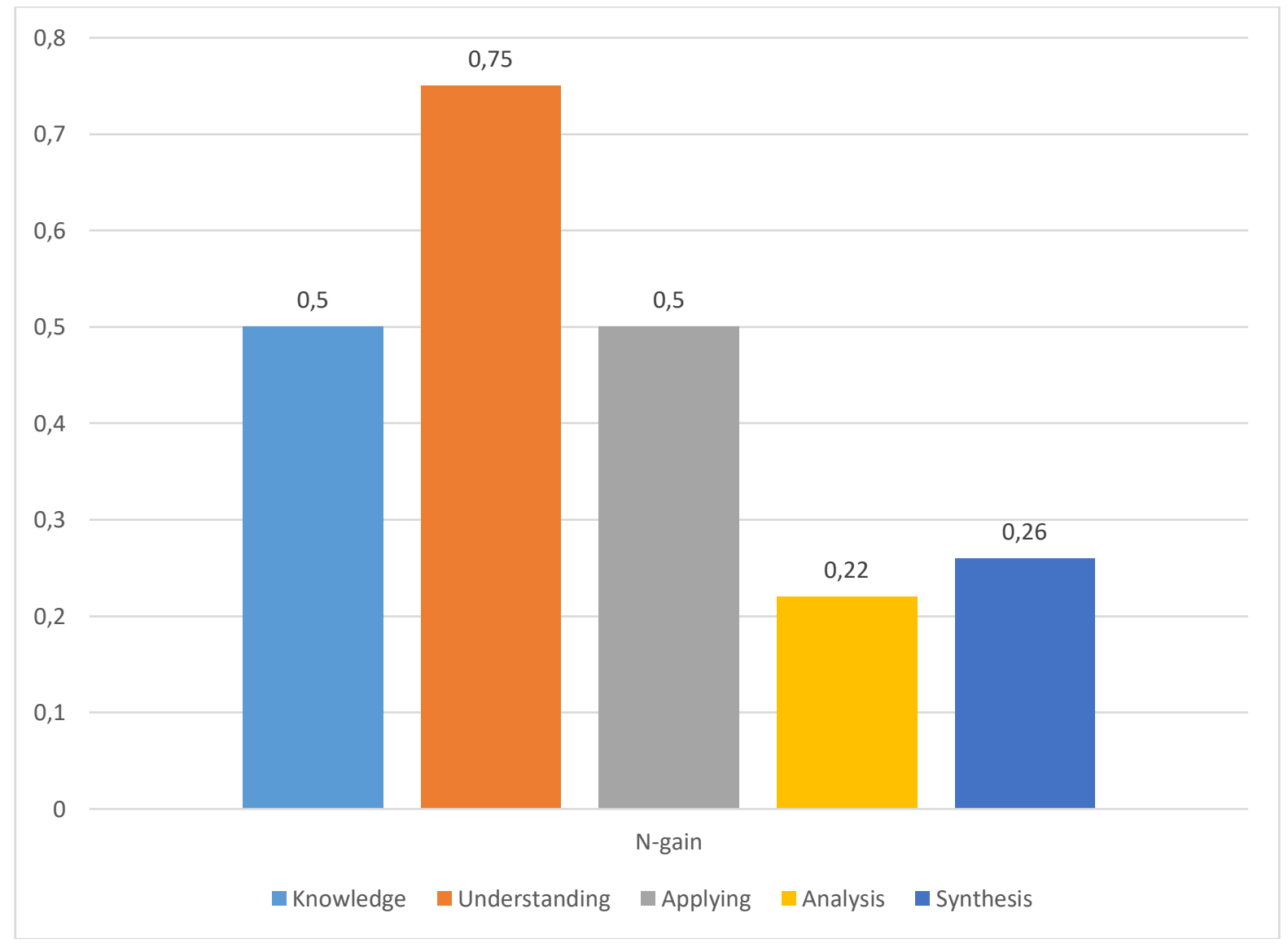

Fig 2. Graph of Improvement of Cognitive Learning Outcomes in every aspect

The results of the comparison between pretest and posttest can be seen in Table 5 with an increase of 0.44 in the medium category. Knowledge aspect has increased by 0.5 in medium category, understanding aspect has increased by 0.75 in high category, application aspect has increased by 0.5 in medium category, analysis aspect has increased by 0.22 in low category, and synthesis aspec has increased by 0.26 in low categories.

Students' Responses To The Implementation Of REACT Learning Models

Data on the results of student responses were obtained through attitude scale sheets after the implementation of the REACT learning model. The data obtained are seen in Table 6. 
Table 6. Attitude Scale Questionnaire

\begin{tabular}{cccc}
\hline \multirow{2}{*}{ Statement Number } & \multicolumn{2}{c}{$\begin{array}{c}\text { Number of Students' } \\
\text { Responses }\end{array}$} & $\begin{array}{c}\text { The number of } \\
\text { students }\end{array}$ \\
\cline { 2 - 3 } & Agree & Disagree & \\
\hline 1 & 24 & 1 & 25 \\
2 & 22 & 3 & 25 \\
3 & 25 & 0 & 25 \\
4 & 23 & 2 & 25 \\
5 & 21 & 4 & 25 \\
6 & 21 & 4 & 25 \\
7 & 23 & 2 & 25 \\
8 & 17 & 8 & 25 \\
9 & 21 & 4 & 25 \\
10 & 21 & 4 & 25 \\
\hline Total Number of & $\mathbf{2 1 8}$ & $\mathbf{3 2}$ & $\mathbf{2 5 0}$ \\
Answers & $\mathbf{8 7 \%}$ & $\mathbf{1 3 \%}$ & $\mathbf{1 0 0 \%}$ \\
\hline Percentage & & &
\end{tabular}

\section{Discussions}

In applying the REACT learning model in this study, relating stage is performed by encouraging students to relating the material to their daily activities, then the researcher listens to the students' responses after being encouraged. Followed by conducting experiencing stage where students are encouraged to carry out the process of searching and investigating the simple machine subjects through learning media that has been provided by researchers. Then in applying stage, researchers provide an explanation of simple machine subjects. At the cooperating stage, researchers dividing students in groups consisting of 4 to 5 people to do group work and exchange opinions in solving problems. And finally transfering stage, where students draw conclusions from the results of group work and presenting them to the class.

The improvement of learning outcomes can be seen from the posttest results which are higher than the pretest results as illustrated in Table 6 , where the average score of posttest results reached 76 , an increase from the pretest results which only reached 56.4. So the increase in learning outcomes is obtained by using the $\mathrm{N}$-gain equation which is 0.44 in the medium category. This proves that the REACT learning model can improve students' learning outcomes in simple machine subjects. Students' learning outcomes have improved from all aspects, as shown in Table 5.

Of all aspects of learning outcomes, aspect of understanding has improved with the highest score reaching 0.75 with high category. This is because at the "experiencing" stage of REACT learning model, students are more active in the learning process. They were directly involved in conducting experiments which ultimately made their understanding significantly increase. This is supported by research conducted by Cahyono et al., states that the REACT learning model has a significant effect on students' understanding [18].

The aspect of analysis has improved with lowest score reaching 0.22 with low category. This is because students are not familiar with the discussion method. This has also been stated in research conducted by Fachruriza and Kartika, that the improvement of the aspect of analysis has improved with low category [13].

As for the aspect of knowledge has increased by 0.5 with medium category, thus the application of the REACT learning model is very effective in improving students' abilities in the aspect of knowledge. What is meant by knowledge here is achieving the ability to remember things that have been learned before [19]. 
As for the application aspect, it increased by 0.5 with medium category. The application aspect is an aspect of students' skills in applying the knowledge they have in a problem solving concept. The effectiveness of the REACT learning model in improving student skills is strengthened by research conducted by Cahyono et al., stated that the REACT learning model has a significant effect on students' science process skills in learning physics [18].

The synthesis aspect has increased by 0.26 with a low category which shows the aspects of synthesis and analysis are lower than the aspects of knowledge and application. In the aspect of synthesis, students have low ability to combine various concepts that makes them less able to solve problems, especially drawing conclusions. This is supported by Munaf who states that the ability of synthesis is the ability to combine elements to form patterns that are logically related, or draw conclusions from events that are related to each other [20].

The recapitulation results from the attitude scale show that $87 \%$ of students stated that they were able to understand simple aircraft material better by using the REACT learning model, as stated in Table 6. It can be concluded that $87 \%$ of students enjoy learning simple machine subject using REACT learning model. The most striking response is that students feel able to carry out the tasks in the student worksheet given, and students feel the REACT learning model is different from previous learning.

\section{CONCLUSION}

Based on the results and discussion above, it can be concluded that the students' cognitive learning outcomes have improved after REACT learning model is applied in the learning process with improvement score of 0.44 in medium category, and student responses to the application of the REACT learning model were positive with percentage of $87 \%$.

\section{REFERENCES}

[1] Puspitasari. (2015). Proses Belajar Mengajar di Sekolah. Jakarta: Rineka Cipta

[2] Kemendikbud. (2003). Undang-Undang Nomor 20 tahun 2003 Tentang Sistem Pendidikan Nasional.

[3] Sudijono, A. (2005). Pengantar Evaluasi Pendidikan. Jakarta: Raja Grafindo Persada

[4] Hakim, T. (2011). Belajar Secara Efektif. Jakarta: Puspa Swara

[5] Wahidmurni. (2010). Media Pembelajaran. Jakarta: Raja Grafindo Persada

[6] Baharuddin, \& Wahyuni, E. N. (2012). Teori Belajar dan Pembelajaran. Bandung: Ar-Ruzz Media.

[7] Djamarah, S. B. (2008). Psikologi Belajar. Jakarta: Rineka Cipta

[8] Herniati, R., Sulistri, E., \& Rosdianto, H. (2017). Penerapan Model Predict Observe Explain Dengan Pendekatan Learning by Doing Untuk Meningkatkan Hasil Belajar Siswa. Jurnal Fisika Flux: Jurnal Ilmiah Fisika FMIPA Universitas Lambung Mangkurat, 14(2): 120-124.

[9] Rusman. (2012). Belajar dan Pembelajaran Berbasis Komputer. Bandung: Wacana Prima

[10] Rosdianto, H. (2017). Pengaruh Model Generative Learning Terhadap Hasil Belajar Ranah Kognitif Siswa Pada Materi Hukum Newton. Jurnal Pendidikan Fisika dan Keilmuan (JPFK), 3(2): 66-69.

[11] Handayani, S., Kusumawati, I., \& Rosdianto, H. (2018). Penerapan Model Learning Cycle 7E Berbantuan Media Visual Untuk Meningkatkan Hasil Belajar Siswa Pada Materi Cahaya Kelas VIII. JIPF (Jurnal Ilmu Pendidikan Fisika), 3(2): 35-37.

[12] Riyanto, A. I., \& Muslim, S. (2014). Penerapan Srategi Pembelajaran React Untuk Meningkatkan Hasil Belajar Siswa. Jurnal Pendidikan Teknik Elektro, 3(2).

[13] Fakhruriza, O., \& Kartika, I. (2015). Keefektifan model pembelajaran relating, experiencing, applying, cooperating, transferring (REACT) untuk meningkatkan hasil belajar siswa SMP pada 
JIPF, Vol. 5 No. 3, September 2020

materi kalor. JRKPF UAD, 2(2): 54-57.

[14] Crowford, M. R. (2001). Teaching contextually: Research, rational and techniques for improving student motivation and achievement in mathematics and science. Texas: CORD.

[15] Riyanto, A. I. (2014). Pengantar Psikologi Umum. Yogyakarta: ANDI

[16] Sugiyono. (2015). Metode Penelitian Kualitatif kuantitatif dan R\&D. Bandung: Alfabeta.

[17] Sugiyono. (2008). Metode Penelitian Kombinasi. Bandung: Alfabeta

[18] Cahyono, B. A. D., Sutarto, S., \& Mahardika, I. K. (2017). Model Pembelajaran REACT (Relating, Experiencing, Applying, Cooperating, Transfering) disertai Media Video Kejadian Fisika Terhadap Keterampilan Proses Sains dan Hasil Belajar Siswa dalam Pembelajaran Fisika di SMA. Jurnal Edukasi, 4(3): 20-24.

[19] Dimyati, \& Mudjiono. (2009). Belajar dan Pembelajaran. Jakarta: Rineka Cipta.

[20] Munaf, S. (2001). Evaluasi pendidikan fisika. Bandung: UPI. 